\title{
Correction to: Socially desirable responding in geriatric outpatients with and without mild cognitive impairment and its association with the assessment of self- reported mental health
}

\author{
Paola Nicolini ${ }^{*}$, Carlo Abbate ${ }^{1,2}$, Silvia Inglese ${ }^{1}$, Daniela Mari ${ }^{1,3}$, Paolo D. Rossi ${ }^{1}$ and Matteo Cesari ${ }^{1,3}$
}

Correction to: BMC Geriatrics 21, 494 (2021)

https://doi.org/10.1186/s12877-021-02435-z

After publication of this article [1], the authors reported that in the Results section, in the sentence beginning 'The lack of significant...', the term 'MCSDshow [?A3B2 $\mathrm{h}=0 \mathrm{pt} ., 128$ ?]S 'should have read 'MCSDS'. Moreover, some small formatting errors have been corrected.

The original article [1] has been updated.

\section{Author details}

'Geriatric Unit, Fondazione IRCCS Ca' Granda Ospedale Maggiore Policlinico, Milan, Italy. ${ }^{2}$ RCCS Fondazione don Carlo Gnocchi, Milan, Italy. ${ }^{3}$ Università degli Studi di Milano, Milan, Italy.

Published online: 22 November 2021

\section{Reference}

1. Nicolini P, Abbate C, Inglese S, Mari D, Rossi PD, Cesari M. Socially desirable responding in geriatric outpatients with and without mild cognitive impairment and its association with the assessment of self-reported mental health. BMC Geriatr. 2021;21(1):494. https://doi.org/10.1186/s12877-021-0243 $5-z$

The original article can be found online at https://doi.org/10.1186/s12877021-02435-z

* Correspondence: paolanikolini@fastwebnet.it

'Geriatric Unit, Fondazione IRCCS Ca' Granda Ospedale Maggiore Policlinico, Milan, Italy

Full list of author information is available at the end of the article

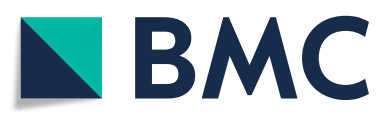

( The Author(s). 2021 Open Access This article is licensed under a Creative Commons Attribution 4.0 International License, which permits use, sharing, adaptation, distribution and reproduction in any medium or format, as long as you give appropriate credit to the original author(s) and the source, provide a link to the Creative Commons licence, and indicate if changes were made. The images or other third party material in this article are included in the article's Creative Commons licence, unless indicated otherwise in a credit line to the material. If material is not included in the article's Creative Commons licence and your intended use is not permitted by statutory regulation or exceeds the permitted use, you will need to obtain permission directly from the copyright holder. To view a copy of this licence, visit http://creativecommons.org/licenses/by/4.0/. The Creative Commons Public Domain Dedication waiver (http://creativecommons.org/publicdomain/zero/1.0/) applies to the data made available in this article, unless otherwise stated in a credit line to the data. 